\title{
Bybellees en wederstrewigheid - lesersreaksie op God en Ester ${ }^{1}$
}

\author{
Gerrie Snyman \\ Departement Ou Testament \\ Universiteit van Suid-Afrika \\ PRETORIA
}

\begin{abstract}
Bible reading and recalcitrance - reader reaction on God and Esther

This article pleads for an open pluralism regarding people's thinking about God. In an answer to the question of how one comes to grips with such a pluralism an aesthetic approach may be instrumental in bringing the biblical text closer to the present-day reader. Such an approach acknowledges an aesthetic distance between the text and its readers. Following Jauß's Asthetische Erfahrung und liferarische Hermeneutik literature is regarded as a communication process in which the author(s), text and readers have equal shares. The approach is illustrated by a reading of the Book of Esther, focusing on Esther's behaviour in chapter 9 and the gaps implying divine action. Instead of a God in control of history, the reading opts for an openness and Gelassenheit towards a notion of holy that is incomprehensible and strange. The article argues against ignoring the human aspect in the reading process which turns Bible reading into an authoritarianism suppressing any imagination.
\end{abstract}

\section{Inleiding}

By die oorsteek van die drumpel na ' $n$ nuwe sosial-politiese bestel is dit in meer as een opsig betaamlik om te besin oor literatuur en Christendom. Wat agtergelaat is, is bekend en beoordeel. Wat voorlê, is die onbekende. Wat agter-

1 Die artikel is 'n verwerking van 'n lesing gelewer by die Intemasionale Konferensie oor "Christendom en literatuur by die eeuwending", gehou by die PU vir CHO op 10-12 Augustus 1995. Ek dra hierdie lesing in 'n verwerkte vorm op aan ds. Johan Myburg, predikant van die Gereformeerde Kerk Oos-Londen, by die toekenning van die Eugene Maraisprys vir sy tweede digbundel. 
Bybellees en wederstrewigheid - lesersreaksie op God en Ester

gelaat is, is die monopolie wat Christelike kerke (of altans, sommiges) op die politiese gebeure tot in 1994 gehad het. Wat voorlê, is 'n doelbewuste erkenning van staatsweë van ander (nie-Christelike) godsdienste. Aan die een kant baan hierdie situasie die weg vir 'n werklike dialoog tussen godsdienste, maar tegelykertyd is daar 'n vrees dat Christelikheid (veral vanuit 'n "wit" perspektief) heeltemal kan disintegreer.

Te midde van hierdie opgewonde spanning sou ek wou hoop dat die nuwe orde wat besig is om te ontluik 'n openheid, of soos Krüger (1995:2) dit stel, 'n oop pluralisme, in die hand sal werk. In plaas van 'n geslotenheid waar alles georden is, almal op hulle plekke is, waar een stem normatief praat vir die ander, sou ek wou sien dat die verskynsel van veelvuldigheid en verskeidenheid in die land aanleiding gee tot die veelheid van stemme wat Michael Bakhtin in die polifone roman raaksien, naamlik 'n veelheid van stemme wat mekaar fundamenteel omskryf en bepaal en wat altyd weer na mekaar verwys wanneer dit in gesprek verkeer (vgl. Goosen, 1992:27). Dit beteken dat nadenke oor god(e) in 'n dialogiese spel 'n veelheid van perspektiewe daarstel waar elke nadenke die eie historiese en wêreldse vooroordele openlik erken en tentoonstel. Die veelheid van nadenke word nie opposisioneel en hiërargies van mekaar afgegrens nie, maar word eerder deur mekaar gekonstitueer (vgl. Goosen, 1992:28).

Die konsekwensie hiervan is dat ' $\mathrm{n}$ gesprek nie meer beëindig kan word met ' $\mathrm{n}$ Wat sê die Bybel nie of 'n So sê die Here nie. Nie alleen is die Bybelteks een van die vele deelnemers in die gesprek (selfs die religieuse gesprek) nie, maar veroorsaak die speelsheid van die gesprek dat die pretensie van goddelike monoloog waarmee veral die Bybelteks belas word, afgebreek word. Op hierdie wyse kan die stem van die teks deel word van die groter geheel van stemme in die gesprek ten einde voorwaardes te skep vir 'n ander (nuwe) interpretasie. Daar is geen bevoorregte posisie van interpretatiewe gesag nie.

Omdat ' $n$ uniforme verstaan van die (Bybel)teks nie moontlik is nie, word dit belangrik om te kyk na daardie faktore wat veroorsaak dat 'n sekere lees van die teks op 'n bepaalde tydstip wel geldingskrag het. Hiervoor is kennis oor betekenisproduksie en die beheer van daardie produksie belangrik (vgl. Beal, 1992). Die betekenis wat uit die teks gegenereer word, staan in direkte verband met die ideologiese raamwerk waarmee lesers die teks benader het. Omdat ideologie egter die gevaar loop om 'n absolute sisteem van sanksionering te word, in die woorde van Krüger (1995:84), "insinuate themselves into the individual's mind and insidiously become an uncritically accepted frame of reference", behoort lesers bewus gemaak te word van hulle eie "strategies of containment" (vgl. Jameson, 1981:54-55) waarmee hulle die werklikheid vir hulleself bevatlik maak. 
Gerrie Snyman

'n Meer "estetiese" benadering sou hier behulpsaam kon wees. Net soos intertekstualiteit alle interpretasies en tekste op gelyke voet stel, net so het lesers ' $n$ gelyke aandeel met die outeur en die teks in die proses van kommunikasie. Daarom word begin met die rol van die mens in die benoeming van 'n literêre werk as "klassiek". Die ervaring van lesers ten aansien van 'n Bybelteks as "klassieke" teks hou verband met die estetiese ervaring waarvan H-R. Jauß praat in sy boek Asthetische Erfahrung und literarische Hermeneutik (1989). Die bespreking begin met 'n omlyning van 'n estetiese benadering, gevolg deur 'n illustrasie aan die hand van die Boek Ester waar twee aspekte na vore kom: die sekulêre rol van Ester en die verborgenheid van God. Vanuit die problematiese rol van God in die verhaal word gekyk na die funksie van verhale as vertellings oor god(e). Enkele gedagtes oor huidige sienings van God word gewissel ten einde aan te dui dat selfs verhale oor $\operatorname{god}(\mathrm{e})$ by grasie van verskeidenheid bestaan. Die artikel sluit af met enkele opmerkings oor die wenslikheid en nut van wat alles gesê is.

\section{Bybelteks as "klassieke" werk}

Literatuur bestaan as literatuur omdat die gemeenskap waarbinne die tekste funksioneer, daardie tekste as literatuur beskou. In die gewone taalgebruik staan dit as klassieke werke bekend. Sulke werke het egter minder te doen met kwaliteit as met lesers wat die werke lees en sodoende lewendig hou. Enige teks het 'n leser nodig om die teks lewendig te hou, en nie soos Clines (1980:127) beweer dat literatuur wat sy naam werd is, die tydsgaping vanself oorbrug nie (vgl. ook Deist, 1994a).

Om die Bybel as literatuur te beskou, is nie sonder probleme nie. Die Bybelteks wat vir 'n bepaalde groep as "literatuur" bekend staan, is gewoonlik die vertaalde vorm (vgl. Carroll, 1993:89). Die Hebreeuse teks is nie ter sprake nie, maar die vertaling wat alleen bestaan by grasie van die gedagte van ' $n$ Heilige Skrif. Om die Hebreeuse teks as 'n grootse literêre werk te beskou, is volgens Carroll (1993:79) 'n "misprision": in die eerste plek is daar nog nie 'n antieke Hebreeuse geskrif waarmee die Bybel vergelyk kan word nie, en tweedens is die taal van die Ou Testament 'n hibriede taal wat niemand gepraat het nie. In hierdie terme is die Hebreeuse Bybel 'n "master narrative" of 'n "cultural text" à la Fredric Jameson $(1981: 29,288)$. Die Ou Testament is onverstaanbaar tensy dit eers geïnterpreteer word en oorgesit word in 'n ander idioom of beeld voordat die teks enigsins bruikbaar kan wees (Carroll, 1993:81).

Die mens speel geen geringe rol in die benoeming van 'n werk as klassieke werk nie. David Tracy (1981:102), wat godsdiens sien as 'n uitdrukking van menslike ervaring (vgl. Sanks (1993:723), meen die volgende: "Every classic 
Bybellees en wederstrewigheid - lesersreaksie op God en Ester

lives as a classic only if it finds readers willing to be provoked by its claim to attention." Sodanige lesers is lesers wat bereid is om 'n risiko te loop om binne hulle eie horison geraak en uitgedaag te word. Die blootstelling om geraak te word deur die literêre teks en die gewilligheid om die spel te speel met die moontlikheid om in die spel verander te word, is deel van die estetiese ervaring. 'n Literêre teks word "klassiek" wannneer die lesers vasgevang word in die wêreld van die teks, of soos Tracy (1981:110) dit stel, "... shocked, surprised, challenged by its startling beauty and its recognizable truth, [...] we recognize the truth of the work's disclosure of a world of reality transforming, if only for a moment, ourselves [...]".

Die rol van verbeelding moenie hier onderskat word nie. Juis omdat daar ' $n$ afstand tussen lesers en die teks is, moet verbeelding gebruik word om die betekenis van die teks te produseer. Dit geskied deurdat die lesers ' $n$ beeld in hulle gedagtewêreld moet opbou waaroor die teks handel. Deur bepaalde vrae aan die teks te stel, betree hulle die wêreld van die teks en begin die rollespel en effektiewe deelname van die lesers aan die produksie van betekenis. En omdat die lesers se wêreld alleen in verskeidenheid bestaan, voer lesers met ander tradisies 'n gesprek oor die betekenis van die teks (vgl. Van Huyssteen 1987:40).

\section{Wat behels die estetiese benadering?}

Die fokus op ' $n$ estetiese benadering kan gesien word as 'n poging om aan die leser 'n groter rol toe te dig teenoor die klemtoon in die verlede op die produksie van tekste en die skrywer. Dié fokus het daartoe bygedra dat die teks in terme van ' $n$ eenvormige betekenis deur lesers gelees is sonder inagneming van die verskillende ideologieë wat in die leesproses ' $n$ rol gespeel het. Omdat ideologieë hulleself verskans teen kritiek, was dit maklik om van die eenvormige betekenis na die enigste betekenis van die teks te beweeg. Ek is van mening dat ' $n$ estetiese benadering lesers sou kon help om los te kom van ideologiserende tendense van heersende belangegroepe wat die teks vir hulle eie doeleindes onderdanig wil maak en op niksvermoedende lesers afforseer.

Jauß (1989:33) se vertrekpunt (sekerlik 'n "strategy of containment") is dat daar ' $n$ afstand is tussen die historisiteit van die lesers se gesigshoeke en die historisiteit van die teks. Hierdie afstand, wat akuut is by antieke tekste, moet deur lesers raakgesien word, anders probeer hulle die gaping niksvermoedend en onnadenkend oorbrug. 'n Estetiese lees is vir Jau $\beta$ 'n proses waartydens lesers deur 'n teks uit hulle alledaagse wêreldjie gehaal word en na 'n ander wêreld geneem word.

Dit is twee wêrelde wat niks met mekaar te doen het nie. Die wêreld waarheen die mens "weggeraap" word, is amper soos 'n wenswêreld en dit vorm die basis 
van die estetiese ervaring. Dit is in hierdie wêreld waar die lesers hulleself op 'n afstand kan herken maar ook ' $n$ ander rol in 'n ander lewensvoorstelling aanneem wat hulle in die alledaagse lewe ontwyk (Jauß, 1989:34). In hierdie ontrukte wêreld neem die lesers vrywillig deel aan 'n spel en doen hulle vrywilliglik wat hulle in die alledaagse lewe verplig word om te doen of dalk verbied word om te doen.

Jau $\beta$ (1989:39) onderskei estetiese ervaring op drie vlakke: 'n reseptiewe, kommunikatiewe en produktiewe vlak.

Op produktiewe vlak, terwyl 'n outeur op papier iets kan sê wat in die alledaagse konvensies en norme onmoontlik is om te sê of te doen (Jauß, 1989:40), is lesers eweneens produktief besig wanneer hulle betekenis in ' $n$ teks skep deurdat hulle 'n wêreld konstrueer waarin hulle denkbeeldige dade kan doen, dade wat dikwels deur ' $n$ monofone rede in die alledaagse lewe verbied word. Om esteties te lees, beteken ook om nie altyd aan heersende belangegroepe onderdanig te wees nie, sodat die waarheid van die teks nie uitsluitlik deur hulle dogmas bepaal word nie. Omdat lesers inderdaad, op grond van dit wat hulle lees, medeskeppers van die outeur se teks word, is die literêre werk meersinnig en kan nie net die outeur verantwoordelik gehou word vir die betekenis wat gegenereer word nie (Jauß, 1989:124).

Op reseptiewe vlak sien Jau $\beta$ (1989:39) estetiese ervaring as iets wat lesers opnuut laat sien. Hier speel gesigshoek en afstand in tyd en ruimte 'n belangrike rol. By 'n antieke teks word lesers eers gekonfronteer met die vreemde en die onbekende soos wat hulle hulleself gedurende die leesproses in die onbekende ou antieke wêreld probeer indink ten einde 'n denkbeeldige objek daarvan te konstrueer. Die proses gaan nog verder deurdat lesers hulle afvra in watter mate die vreemdheid en onbekendheid van die teks 'n nuwe antwoord bied op 'n geldige vraag waarmee hulle worstel. Met ander woorde, die lesers kyk na die vrae waarop die teks eens 'n antwoord was ten einde uit te vind of daar vrae is waarop die teks aanvanklik nie antwoorde verskaf het nie, maar nou wel oplossings voor kan gee (vgl. Jauß 1987:3).

Op kommunikatiewe vlak verskaf die estetiese ervaring 'n genot wat sowel tot 'n verandering van oortuiging as 'n bevryding van bepaalde gevoelens kan lei, as gevolg van die emosies wat lesers ervaar het by die lees van die teks (vgl. Jauß 1989:166). Dit gebeur deurdat lesers in staat gestel word om bepaalde rolle te aanvaar en uit te speel. Op grond van hierdie moontlikheid word lesers in staat gestel om dit wat in die alledaagse lewe onbereikbaar is, moontlik te maak.

Hoe sou hierdie proses nou kon werk by die lees van 'n Bybelteks? Vanuit 'n twintigste-eeuse benadering tot geweld, en vanuit die spiraal van geweld in die 
Bybellees en wederstrewigheid - lesersreaksie op God en Ester

land op die oomblik, lewer die Jode se hantering van die Perse, na die ommekeer van Haman se doodsdreigement, probleme op. Ester se versoek in Ester 9 dat die Jode nog 'n dag moet bekom om hulle vyande dood te maak, bring die vraag op (by my) of Ester in hierdie geval nie bloeddorstig optree nie. Of is sy net prakties en realisties? Meer nog, as God in die verhaal verantwoordelik gehou kan word vir die ommekeer in die Jode se benarde posisie sonder dat ' $n$ enkele een sterf, hoekom moet die Perse die spit afbyt terwyl hulle in die teks juis positief teenoor die Jode staan? Trouens, dit is asof die Jode juis dit doen wat die Perse wou doen.

Die vraag na die vreemde aksentueer die afstand tussen die latere leser en die antieke teks. Die vrae wat latere lesers aan die vreemde antieke teks vra, is onortodoks en byna ketters. Maar juis dit is die kenmerk van die estetiese benadering: nie-onderdanigheid en ' $n$ illegitieme verwondering deurdat die teks die lesers tot sekere vrae uitnooi omdat die teks nie alles op die tafel plaas nie en sekere sake duister hou.

\section{Ester en die versluierde God}

Lesers van die Boek Ester konstrueer 'n wêreld waarin hulle saam met die karakters in die storie rondbeweeg. Hoofstuk een dek eintlik die tafel vir die res van die boek deurdat die lesers bekend gestel word met die toneelskikking, naamlik ' $n$ paleis in die stad Susan, 'n koning met onbeperkte mag en raadgewers wat eintlik die mag het en 'n koningin wat nie na die koning wil luister nie. Vanuit 'n materialistiese perspektief (vgl. Mosala, 1992) kan lesers 'n vervreemdende afstand ervaar, soos ten opsigte van die ekonomiese surplus wat vir partytjies en 'n luukse leefstyl aangewend word in plaas van om mense op te hef (van laasgenoemde armes hoor mens glad nie in die verhaal nie). Vanuit 'n Westerse demokratiese beskouing (vgl. Clines, 1992 en Mosala, 1992) is die politieke mag in die verhaal feodaal van aard deurdat besluite alleen op die ondergeskiktes afgedwing word.

Deur die hele verhaal is God op die agtergrond. Sy naam word nie een keer in die Hebreeus genoem nie. Die vraag is of hy enigsins aan die werk is in die verhaal. Loader (1992:221) maak baie van die verswyging van God se naam. Deur middel van 'n spel van intertekstualiteit deur doelbewus die Eksodus- en Josefverhale op te roep, word 'n beeld van goddelike optrede geantisipeer. In albei die verhale vind ' $n$ ommekeer van rolle plaas deurdat God die verdrukte telkens sy verdrukking laat afskud. Die oproep van parallelle verhale veroorsaak met ander woorde by die lesers 'n verwagting dat God ook só in die Boek Ester sal optree sonder om hom regstreeks 'n rol toe te dig.

Loader praat van 'n Lücke: God is nie te sien nie, maar sy teenwoordigheid word op ' $n$ bedekte wyse gesuggereer. Hierdie gapings versluier volgens 
Gerrie Snyman

Loader (1992:224) God se optrede ten einde 'n literêre uitdrukking te vind vir die oortuiging dat God se optrede in die wisselvallighede van die lewe verberg word. Loader sê die skrywer kon soos in die Josefverhaal God se optrede konkreet gemaak het, maar hy het nie. Daarom is dit nie korrek om goddelike handelinge naas die menslike inisiatief te plaas nie. Die indruk van die verhaal is dat God ook in die werklike lewe verborge is. God is nie daar nie, hy kan maar net geglo word. Die Boek Ester is daarom vir Loader 'n weerspieëling van die lewe: die geheel kan gelees word as 'n sekulêre onderneming, of dit kan onder die beheer van 'n onsienlike, onopvallende God geplaas word.

Die probleem is egter dat die sekulêre onderneming nie altyd met die goddelike optrede versoenbaar is nie. As God op die een of ander manier in beheer is, hoekom tree Ester soms op asof sy haar godsdiens verloën?

As ons aanvaar (argumentsonthalwe) God is agter die plan om Ester in die Persiese paleis te kry, dan kry Ester se oproep om te vas (Ester 4:6) en haar brief oor die korrekte viering van die Purim (Ester 9) religieuse betekenis. Sy vind dit belangrik om sekere godsdienstige rituele in tye van nood en blydskap uit te voer.

Wanneer Ester se optrede egter in die lig van Vasti se ongehoorsaamheid gesien word, dan begin goddelike intrede problematies word. Vasti se voorbeeld het veroorsaak dat Ester versigtiger en meer in ooreenstemming met Persiese gebruike en minder in ooreenstemming met Joodse gebruike optree (vgl. Day, 1995:213).

$\mathrm{Na}$ die afsetting van Vasti gaan Ester as jong meisie saam met ander na die koning se harem, met die oog daarop om koningin te word. Sy tree hier teen Joodse voorskrifte en lewensreëls op. Hoe kan 'n Jodin haarself aan 'n nie-Jood beskikbaar stel? Clines (1992:47) is van mening dat dit een van die suksesvolste maniere is om jou identiteit te verloor. Hier moet die lesers 'n paar dinge in gedagte hou: dit was skynbaar nie 'n probleem om só 'n huwelik tydens die ballingskap aan te gaan nie. Vergelding sou in alle geval nie Ester te beurt geval het nie, omdat sy met 'n nie-Jood getroud was. Dit was eerder die vreemde vroue wat later deur Nehemia weggejaag is. Maar Ester se optrede is vanuit die gesigshoek van die naballingskapse Jodendom problematies, omdat Levitikus 20:22-26 die Jode verbied om die praktyke van die heidennasies na te volg. Hulle was immers God se uitgesoekte en afgesonderde volk wat nie ander wette nagevolg het nie, aldus Haman in Ester 3:8. Verbreek God nou sy eie wette om die Jode, wat in ballingskap sit vir straf, uit die pekel te haal?

Was Ester net gelukkig om koningin te word? Volgens Moore (1988:21) het Ester iets van haar kant gedoen om Hegai se guns te wen (Ester 2:9) hoewel dit nie onmoontlik was dat Hegai geweet het waar sy brood die dikste en lekkerste 
gebotter was (Moore, 1988:27). Volgens die patriargale stelsel moes Ester hom as haar meerdere gehoorsaam (sy gehoorsaam selfs Mordegai terwyl sy in die harem is). Ester was aanpasbaar maar eweneens prakties en realisties oor haar kanse. As koningin het haar Joodse identiteit op die agtergrond getree, en daarmee saam haar godsdienstigheid.

Wanneer Mordegai in Ester 4 haar hulp kom vra in verband met die doodsbevel van Haman, lyk Ester nie te gewillig nie. Mordegai moes haar dreig met 'n "verligting" wat van 'n "ander kant" sal kom. Aan die een kant is Ester dalk eerder realisties oor haar kanse op oorlewing, gegewe wat met Vasti gebeur het. In alle geval, sy was op daardie stadium ook nie meer deur die koning ontbied nie. As sy nou ongevraagd by die koning sou opdaag, het sy dalk omgekom.

Haar huiwering dui egter op 'n bepaalde afstand tussen haar en die Joodse volk. Sy stem weliswaar in om Mordegai te help, maar 'n mens kry die idee dat sy dit doen omdat sy gedreig is, eerder as vanuit innerlike godsdienstige oortuiging. Sy gebruik ook haar vroulike lis en skoonheid om die koning se belangstelling in haar te wek en om Haman uiteindelik te ontmasker. Wanneer sy laasgenoemde doen in Ester 7, is haar optrede weer eens dubbelsinnig. Haman smeek haar om genade, maar Ester swyg. Sy staan daar, soos Anderson haar in Moore (1988:74) beskryf: "[V]ictorious through the exercise of her feminine charms but callous and indifferent as the once proud heathen asks for mercy." Is sy bloeddorstig of gewoon prakties en realisties? Moore meen eerder dat Ester hier prakties is, want Haman het op daardie oomblik nog nie verloor nie. Het Ester hom gehelp, sou hy nog steeds in staat wees om met sy doodsbevel teenoor die Jode voort te gaan.

In hoofstuk 9 vra Ester vir 'n tweede dag van verdediging wat uitloop op verdere bloedvergieting van die Perse. 'n Mens vra jouself die vraag af of sulke bloedvergieting regtig nodig was, veral as die Perse in die verhaal die Jode goedgesind is en daar nie juis weerstand is nie. Hulle het hulle pas tot die Jodendom bekeer (Ester 8:17). Die geweld waaraan hulle probeer ontkom, rig hulle nou self aan! Goldman (1990:27) sê die verhaal stel die Jode voor as uitgeslape en tot net sulke geweld as die Perse in staat. Hoe gemaak met 'n god wat sulke geweld sanksioneer?

Vanuit 'n laat twintigste-eeuse perspektief laat Ester die indruk van bloeddorstigheid. Dit wil voorkom of die Jode in Susan hierdie bloeddorstigheid deel deurdat hulle selfs van die Persiese metodes gebruik maak om diegene wat hulle wou uitwis te dood. Met Ester en Mordegai in die paleis het die volk deel van die Persiese sisteem geword (vgl. Clines, 1992:46). Dit is asof hulle die rede wat Haman aanvoer om hulle uit te wis ook wil uitwis, naamlik hulle Joodsheid (wat die navolging van sekere wette behels). 
Gerrie Snyman

Of was Ester nou maar net realisties om "doodseker" te maak dat alle weerstand uit die weg geruim is? Enige oorblyfsel van Haman se nagesiag sou die stryd dalk later verder gevoer het, soos die vermelding van Haman en Mordegai se geslagsregisters in die storie suggereer. Hulle geslagsregisters vertel van 'n religieuse konflik wat dateer uit die dae van Israel se omswerwinge in die woestyn (Loader, 1992:240)².

Maar hoe bring die lesers God en die karakter Ester bymekaar uit? Vir Helberg (1983a:157-159) is dit nie 'n probleem om God in die verhaal raak te sien nie: hy staan verwonderd oor God se regering wat hy in die Boek Ester raaksien:

Op 'n wonderbaarlike manier regeer Hy hulle deur ander nasies en regeer $\mathrm{Hy}$ ander nasies deur hulle. Sy planne is hoog, verhewe en onpeilbaar diep. Daarom kan daar op Hom vertrou word en kan alles aan Hom oorgelaat word. $\mathrm{Hy}$ is die heerser oor dood en lewe. (My kursivering - G S.)

Die swye van God se naam is juis vir Helberg ' $n$ teken van die boek se kragtige getuienis oor God se wonderbaarlike regering. Hy bestier die geskiedenis tot in die kleinste besonderhede. Hy voer sy heerskappy deur, al word hy nie erken en word sy naam nie bely nie. Sy heerskappy strek ook nie net oor die bondsvolk in Jerusalem nie, maar ook oor diegene wat nie teruggekeer het nie en ook oor die Persiese ryk in wie se midde die volk nog leef. Al het die Here verlos, meen Helberg (1983a:158) het dit groot inspanning en volharding van die mense gevra. Die ommekeer van rolle wat plaasvind, dui vir Helberg op 'n eskatologiese sinspeling waarvolgens die geskiedenis uitloop op die dood van die volk van God, maar wat dan deur wonderbaarlike redding en oorwinning as't ware deur die Here van ondergang gered word.

My probleem met só 'n lees van die boek is dat die etiese vraag na die wyse van goddelike optrede nie na vore kom nie. Watter soort goddelikheid sit agter 'n "wonderbaarlike regering" waar die een volk se redding die ander een se ondergang is? Is die stryd in die Boek Ester 'n stryd tussen die Jode en hulle vyande (die Perse) of tussen Mordegai en Haman? Die Jode het baie van die Persiese kultuur oorgeneem, selfs hulle skrif (Bal, 1991).

2 Haman verteenwoordig die Amelekiete wat al sedert die dae van omswerwing in die woestyn 'n doring in Israel se vlees was. Agag, die Amelekiet, duik weer op in die tyd van Saul, die seun van Kis uit Benjamin. Saul moes dié koning dood gemaak het, maar hy het hom gespaar. Samuel moes tóé doen wat Saul nie gedoen het nie (1 Samuel 15). Mordegai kom uit die geslag van Benjamin en van Kis met ander woorde, Ester (en Mordegai) moet afhandel, voltooi wat Israel en Saul nie afgehandel het nie. 
'n Ander omweg sou wees om, soos Loader, aan God 'n minder direkte rol toe te dig en die verhaal binne 'n wysheidsraamwerk te plaas waarbinne die karakters se optredes gemeet kan word. Ek meen dat die intrigepatrone van die chaotiese en geordende wêreld hier van nut kan wees. Hierdie intrigepatrone help die lesers om die storiewêreld, of die estetiese objek, te konstrueer. 'n Chaotiese wêreld binne die wysheidsdenke van daardie tyd is 'n wêreld waar daar nie harmonie met God is nie. Die skeppingsgorde is versteur, mense tree dwaas op en die uiteinde van hulle dade is mislukking. Hierteenoor is die geordende wêreld daardie wêreld waar die skeppingsorde juis gehandhaaf word, waar mense wys optree en hulle optrede met sukses bekroon word. In die Esterverhaal is dit duidelik dat Mordegai en Haman die twee pole van wysheid en dwaasheid vorm (vgl. Deist, 1986; Loader, 1986).

Hierdie raamwerk plaas Ester op die grens tussen die geordende en die chaotiese wêreld. Deur koningin te word, moes sy sekere Joodse gebruike verloën. Haar huiwering om die Jode te help (Mordegai moes baie hard met haar praat om haar te oorreed), wys hoever sy dalk in die chaotiese wêreld ingetrek is. Tog neem sy 'n wyse besluit deur die Jode wel te help. Waar sy voor die tyd bang was om haar lewe te verloor as sy ongenooid by die koning ingaan, bly sy juis lewe wanneer sy by die koning ingaan. Ester tree voortdurend wys op deur die regte ding op die regte tyd te verswyg, te sê of te doen. En sy behaal sukses, want deur haar wysheid kon die doodsboodskap van Haman omgekeer word. Binne hierdie raamwerk is dit geldig om te beweer dat God aan haar kant is.

Haar versoek van 'n ekstra dag om die Jode toe te laat om hulle vyande dood te maak, kan egter nie in terme van wysheid beantwoord word nie. Wat die lesers wel agterkom, is dat die Purimfees twee dae duur. Die afleiding is omdat die fees twee dae lank is, moes die tweede dag op een of ander wyse geregverdig word. Dit is gedoen deurdat Ester (tot nadeel van haar karakter) vir ' $n$ tweede dag van bloedslagting vra. Hierdie afleidings impliseer met ander woorde dat die leser voortdurend besig is om sekere gapings in die teks te vul na aanleiding van sekere intertekstuele elemente of intratekstuele elemente.

\section{Hoe gemaak met God ... ?}

Die Boek Ester is 'n Persiese kroniek sonder enige uitdruklike vermelding van die Joodse God Jahwe. Hierdie gegewe staan in skrille kontras met daardie verhale waar God se werk vooropstaan, soos in die koninklike geskiedverhale. Dié verswyging sê reeds iets van die godsdiensbegrip uit daardie tyd: die klem val op persoonlike vroomheid in 'n familiale verband (vgl. Albertz, 1992:422427; Snyman, 1995). Omdat die Jode afhanklik was van die goedgunstigheid van die Perse as politieke mag, is die Joodse god eenvoudig nie meer in hulle 
geskrifte genoem nie. God is op 'n afstand geplaas en die Joodse godsdiensbelewenis het uiting gevind in wysheid waar menslike optrede vooropstaan. Tree mense dwaas op, moet hulle die verantwoordelikheid van mislukking dra. Is hulle wys, word hulle deur God geseën. God is alleen ter sprake in dié sin dat Hy die raamwerk van optrede verskaf, naamlik 'n geordende wêreld. Dit is dan ook hierdie siening wat die boek vir die twintigste-eeuse leser kan legitimeer: wyse optrede bring sukses in die hand, terwyl dwase optrede op mislukking afstuur.

Die mens se siening oor God het 'n ontwikkeling ondergaan. Een geslag se idee van God was nie noodwendig gepas vir 'n volgende geslag nie (vgl. ook Armstrong, 1993). Mense moet daarmee rekening hou dat die godsbeeld in die Ou Testament polifonies is, gekleur deur bepaalde ideologiese, ekonomiese en politieke perspektiewe uit die tyd toe die betrokke verhaal oor die godheid finaal op skrif gestel is. Dit is egter die projek van die moderniteit wat die verskillende weergawes van mense se godsbeelde as histories kontingente perspektiewe ignoreer en alles wil reduseer tot een godsbeeld (vgl. Toulmin, 1990:55). Die moderniteit wil met sy rasionele argumente meetbaarheid moontlik maak en sekerheid verskaf, sodat mense God in terme van vastigheid en sekerheid kan vasvang ${ }^{3}$. Op hierdie wyse word die onberekenbare en die onmanipuleerbare ten minste uitgeskakel. Die mens is op soek na 'n vaste verwysingspunt en 'n laaste waarheid. Die soeke na só 'n verwysingspunt het gelei tot die aanvaarding van ' $n$ waarheid wat bestaan ongeag en onafhanklik van die mens (Du Toit, 1988:37). Die waarheid is gevind in 'n rede wat die wêreld sinvol konstrueer en interpreteer sodat alles 'n eenheid vorm en pas binne 'n beheerbare orde wat vir die mens bevatlik is (vgl. Du Toit, 1988:43). Hierdie denke het verder daartoe gelei dat die mens in 'n magsgreep van wetenskap en tegniek vasgevang is (vgl. Le Roux, 1994), sodat die mens in die menswetenskappe (teologie ingesluit) sowel as in die tegniek geminimaliseer is.

Heidegger (1959:13) het vroeg reeds gewaarsku teen die oorweldiging van die tegniek wat maak dat die mens onnadenkend geword het. In die menswetenskappe word hierdie onnadenkenheid van die mens geillustreer deur die vrese dat sekerheid verlore sal gaan wanneer die mens ' $n$ te groot rol in die generering van kennis toegedig word. Hierdie vrees is skynbaar akuut in die Bybelwetenskappe wanneer gepleit word dat die menslike andeel buite

3 Die strewe na sekerheid as kenmerk van die modemiteit is verantwoordelik dat ortodokse teoloë probleme ervaar met enige benadering wat die rol van die mens beklemtoon. Enige bydrae van die mens steun op die mens se eie skeppingsvermoë. Dit beduiwel sekerheid want die mens kan sy of haar eie motiewe in die Bybel indra (vgl. Jordaan, 1991). 
Bybellees en wederstrewigheid - lesersreaksie op God en Ester

rekening gelaat moet word uit vrees vir ideologisering en verdraaiing van die een redelikheid en die een waarheid (vgl. Helberg, 1983b:61 en Jordaan, 1991).

Hierteenoor meen ek dat mense alleen van die mag van die tegniek en 'n monofone Bybelteks bewaar kan word deur hulle estetiese sin en bewussyn te kultiveer (vgl. Le Roux, 1994:598). Goosen (1992:28) verwys na 'n veelheid van perspektiewe wat gekenmerk word eerder deur 'n verwikkelde dialoog waarin "elke teologiese perspektief haar eie filosofiese erfgoed medeveronderstel, elke waarheidsaanspraak haar eie ideologiese aanknopingspunte ruiterlik erken en elke rede oor God haar eie historiese en wêreldsc vooroordele openlik ten toon stel" (my kursivering - GS).

Teenoor moderniteit se onnadenkenheid staan die postmoderniteit se bewussyn van die mens se subjektiwiteit. Die gevolg is dat die werklikheid eerder in veelvuldigheid en in differensiasie na vore tree. Vir die postmoderne is daar nie meer 'n sentrum nie, maar alleen 'n lewe in meervoud (vgl. Ijsseling, 1994:8). Hoewel keuses gemaak word en besluite geneem word, word finale oordeel uitgestel.

In die religieuse teks gaan dit nie oor die monofone (goddelike) stem as "godsopenbaring" nie, maar die dialogiese aanwesigheid van die ander as voorwaarde vir die eie subjektiwiteit. Daar is iets "Dionisies" aan die mens se subjektiwiteit. Die antieke Dionisoskultus het altyd die bestaande orde in twyfel getrek deur 'n ander aspek van heiligheid te onthul (vgl. ljsseling, 1994:25). Die heilige was nie so stabiel of vasomskrewe nie maar eerder vreemd en onbegryplik. Die antieke Griekse gode het juis in hulle verskeidenheid bestaan. En die begrip van heiligheid het geen eenheid vertoon nie: die "heilige" was verbrokkel en het bestaan by grasie van die verskeidenheid (ljsseling, 1994:176).

Daar is altyd ' $n$ moment wat verstaan en begripsmatigheid ontwyk. Rudolp Otto (Otto, 1950:3, vertaling van 'n teks uit 1917) het hierdie verskynsel aan die begin van die eeu 'n mysterium tremendum et fascinans genoem, en dit gekoppel aan 'n verwondering oor die heiligheid van God. Maar waar hierdie verwondering vir Otto die gevolg is van iets buite die mens se subjektiwiteit, word dit binne die postmoderne raamwerk juis deel van daardie subjektiwiteit. Dit wat oor gode gesê word, is ' $n$ aanduiding van hoe mense hulleself met hulle omgewing integreer (vgl. Vorster, 1994:128-129). Dit is juis deur middel van verhale dat mense in staat is om betekenis en struktuur aan hulle lewe te gee te midde van die chaotiese oop ruimte waarbinne hulle lewe.

Die menslike ervaring van verbrokkeldheid en veelvuldigheid word geillustreer deur die belangrikheid wat verhale toenemend verkry (Fisher, 1987:58; Snyman, 1994). ljsseling (1994:177) tref die onderskeid met die ou Griekse 
Gerrie Snyman

gode wie se optredes alleen fragmentaries weergegee word. Hulle verhale kan nie begryp word nie, maar alleen vertel word. Omdat begrip uitgestel word, is al wat soms oorbly om die verhale op te roep en net weer te vertel, in ' $n$ ander plek, op 'n ander tyd in 'n ander konteks (Ijsseling, 1994:196). Elke nuwe vertelling is maar net ' $n$ voorbeeld van 'n swak en beskeie denke wat nie alles wil omvat en begryp nie, wat nie wegskram om deur die ou waarhede aangespreek te word nie en wat ook oopstaan vir die onbegryplike, die onbeheersbare, die andere en die geheim (vgl. ook Keegan, 1995:1). Dit het gevolglik weinig sin om te vra of die verhale histories waar is. Die verhale het meer trefkrag deur middel van karakters wat navolgenswaardig of afskrikwekkend optree. Die karakters is spieëls waarin mense hulleself kan ontdek en wat aan hulle ' $n$ identiteit verleen.

Dit het minder sin om te praat of Ester regtig geleef het as om te kyk na haar spieëlbeeld. Daar is baie wat 'n mens aan Ester kan beny en bewonder: haar moed, slimheid, doelgerigtheid, skoonheid. Maar kan 'n mens regtig met haar assosieer, veral wanneer sy om 'n tweede dag van bloedvergieting vra? Miskien is sy 'n tragiese held, iemand wat verkeerde dinge moet doen ten einde te kan oorleef. Die prys wat sy betaal, is om soos die Perse te word en om die patriargale sisteem te onderhou teenoor Vasti wat daarteen gerebelleer het.

En die soort godheid wat tussen die reēls van die verhaal lê? Die god wat raakgesien en meetbaar gemaak word, is 'n Joodse god wat veg vir Joodse belange ten koste van 'n bevolking wat die Jode goedgesind was, wat saam met die Jode ontsteld was oor Haman se doodsdekreet was en wat later selfs tot die Jodendom bekeer is! So 'n verstaan bring die vraag na die nut van 'n partydige en nasionale godheid by die eeuwending na vore.

Hierteenoor kan die klem op die verhaal en wat die karakters doen, lesers in staat stel om met die karakters positief of negatief te identifiseer. Mense hou van stories, want plot, karakters en die estetiese kwaliteit van taal maak verhale meer interessant as doodgewone argumentatiewe tekste. Verhale doen dinge wat ander literatuurvorme nie doen nie. Deur middel van verhale is mense in staat om vrede te maak met wie en wat hulle is en watter rol hulle in die gemeenskap kan speel. Dit is deur middel van verhale dat mense perspektief op die probleme in die wêreld kan verkry (Rowland, 1987:267-268).

Een van die aspekte van die estetiese benadering is dat die literêre werk (of gedrukte teks) 'n effek op die lesers het. Elke verhaal het 'n etiese appèl wat na die lesers of hoorders uitgaan. Enigeen wat intens met 'n verhaal meeleef, weet dat daardie verhaal gedrag beïnvloed. Booth (1988:229) maak melding van die feit dat die werklike lewe geleef word in terme van beelde wat uit stories kom. Mense volg karakters na: 
Bybellees en wederstrewigheid - lesersreaksie op God en Ester

Indeed, our imitations of narrative 'imitations of life' are so spontaneous and plentiful that we cannot draw a clear line between what we are, in some conception of a 'natural', unstoried self, and what we have become as we have first enjoyed, then imitated, and then, perhaps, criticized both the stories and our responses to them.

Die begeerte om iets van die lewe te leer en te verstaan is steeds een van die grootste dryfvere agter die lees van 'n lekker verhaal of roman. En lesers leer! In hierdie terme word 'n klassieke werk gereken as 'n werk waar mense voortdurend iets te leer vind, asof die werk 'n onuitputlike bron is van nuwe dinge. Juis vanweë hierdie effek verkry die teks 'n besondere status as literatuur.

\section{Ten slotte}

Die kern van die estetiese benadering is die Selbstgenu $\beta$ im Fremdgenuß. Die lesers, wie se eie vermoëns geaktiveer word in die leesproses, betree 'n spel met die teks. Soms verdoesel die teks die reëls van die spel, sodat die ontdekking daarvan deur lesers op sigself 'n speletjie word. Deurdat die lesersvermoëns geaktiveer word, word die lesers van hulle eie teenwoordigheid bewus gemaak, met die gevolg dat hulle in staat is om hulleself dop te hou in die spel met die teks en die rol wat die spel van hulle vereis.

Deurdat 'n estetiese benadering erkenning gee aan die rol van lesers in die leesproses, is (natuurlikerwys?) 'n weerstand en nie-onderdanigheid by die lees van tekste te verwagte. Dit is weerstand teen interpretasie wat finaal en afgesluit is. Die lewe in veelvoud maak dat verstaan uitgestel word, want daar is altyd die miskien van iets anders. Die hele geskiedems van die Christendom dui op 'n geskiedenis van 'n veelvuldigheid van interpretasie wanneer nuwe lesings telkens na vore kom.

Daar is natuurlik ook politieke redes waarom weerstand teen 'n enkele interpretasie onder teologiese wetenskaplikes voordelig is. Keegan (1995:10) sê dié weerstand, wat hy veral in die Rooms-Katolieke kerk sien, gaan minder oor 'n getrouheid aan leerstellings en tradisie as om 'n begeerte om beskerm te word teen inmenging van ' $n$ gesagvolle kerk in akademiese aangeleenthede.

Die toepassing van literêre benaderings ten opsigte van die Bybelteks het nuwe probleemareas geopen en op só 'n wyse nuwe denke gestimuleeer (vgl. Deist, 1991:78). 'n Erkenning van die onderskeid tussen verskillende wêrelde ${ }^{4}$ wat

4 In die hoofberig (Zaaiman, 1995) van Beeld se Boekeblad op 19 Julie word vertel van die Christelike waardes in Marlene Van Niekerk se boek Triomf. Die vraag is natuurlik hoe 'n boek waar die karakters in bloedskande leef, vloek, suip, gods- 
Gerrie Snyman

betrokke is by die leesproses is seker een van die belangrikste bydraes wat die literatuurteorie aan die lees van Bybeltekste gelewer het. Die onderskeid tussen die wêreld van die produksie van die teks, die historiese wêreld waarna die teks verwys, die wêreld wat in die teks self geskep word, en die wêreld waarbinne die lesers staan, verbreek die reglynige kommunikasie tussen teks en lesers, sodat lesers hulle verbeelding behoort te gebruik om betekenis in die teks te genereer. En die mate waarin lesers betrokke word by die lees van 'n teks maak Bybellees lekker.

Teenoor 'n pessimisme dat "oorsese" benaderings te klakkeloos oorgeneem word en verhoed dat Suid-Afrikaanse teologie 'n eie Afrika-identiteit kry (Deist, 1994b:39), meen ek dat die fokus op die lesers juis die eie konteks behoorlik in ag neem. Omdat die fokus in 'n postmoderne lees nie meer val op 'n objektiewe transendentele element nie, maar op karakters en verskillende wêrelde, ontstaan daar ' $n$ dinamiek tussen die leser se onmiddelike leefwêreld, die vertelde wêreld en die wêreld van produksie, sodat 'n karakter se optrede (soos dié van Ester) nie altyd goedskiks oorgedra word na die leser se eie

lasterlik praat Christelike waardes kan weerspieël. Volgens Zaaiman het Van Niekerk baie van haar formuleringe uit die Bybel gekry, en dit op só 'n wyse deurgegee dat dit hoegenaamd nie die sus of streel nie: "Sy wou nie net dit bevestig wat ons reeds voel en glo, of dink dat ons behoort te voel en glo nie". Die karakters versinnebeeld op die ou end die Christelike waardes soos bekering, opoffering, en uitreiking na ander mense. So iets is alleen moontlik wanneer lesers raaksien dat 'n skrywer nie biografiese gegewens in 'n boek sit nie, maar dat die werklikheid, om waarheid te kan wees, in fiksie na vore kom. 'n Skywwer skep ' $n$ fiktiewe werklikheid in 'n verhaal en in daardie werklikheid doen karakters sekere dinge, veral dinge wat die skrywer self nie eers in die werklike lewe sal doen nie. Immers, het iemand al vir Jessica Fletcher van moord verdink? 'n Skrywer behoort nie opgehang te word vir die moorde wat in 'n teks gepleeg word nie. Maar dit beteken nie dat die skrywer onbeïnvloed is deur die wêreld waarbinne die teks geproduseer is nie. In dieselfde uitgawe van Beeld se Boekeblad vertel Adam Small, wat geen "Jesus fan" is nie, hoe die Bybel een van sy bronne vir sy werk is (vgl. Wyngaard, 1995). En terloops, in hierdie uitgawe van Beeld se boekebylaag is daar nog twee ander berigte buiten bogenoemde twee wat die Christendom aan sekulêre literatuur koppel: elders in die bylaag word ook vertel van vyf jong predikante-digters wat hulle eerste digbundel (Ons kom van ver a) uitgegee het (vgl. Anon., 1995:2). En dan is daar 'n onderhoud met Johan Myburg, predikant van die Gereformeerde Kerk Oos-Londen, wat die Eugène Marais-prys vir sy tweede digbundel, Kontrafak, ontvang het (Toerien, 1995:6).

Koers 6l(I) 1996:37-55 
Bybellees en wederstrewigheid - lesersreaksie op God en Ester

konteks nie. Mens sou ook verder kon gaan om soos Davies (1995:35) te beweer dat, omdat die leser die plek is waar betekenis gegenereer word, "ware" betekenis aan mense gegee word wat vervul is met die Heilige Gees (kyk ook Botha, 1986:278). So 'n benadering help ook om lees te vrywaar van die beskuldiging van "subjektivisme" deurdat "objektivisme" uitgedaag word. Maar ek dink veral dat postmoderne benaderings eerder ' $n$ uitdaging bied aan teologie wat gebaseer is op 'n objektiewe realiteit waarheen die Bybel verwys omdat aanvaar word dat tekste nie na 'n werklikheid buite hulleself kan verwys nie (vgl. ook Vorster, 1994).

Miskien moet die laaste woord aan Jacques Derrida gegee word. In 'n onderhoud gee Derrida (1994:28) onder andere 'n uitspraak wat sterk herinner aan Scholes (1968:3) se uitspraak dat feite, ten einde te kan oorleef, fiksie moet word: "[actuality] is sorted, invested and performatively interpreted by a range of hierarchising and selective procedures - factitious or artificial procedures which are always subservient to various powers and interests of which their 'subjects' and agents [...] are never sufficiently aware".

Die teks nie word net op sigwaarde geneem nie, maar die hele proses van produksie daaragter moet ook in ag geneem word indien ons iets van die teks wil verstaan. Die estetiese benadering beklemtoon die rol van die lesers in die leesproses. By die lees van antieke tekste hou hierdie rol nie net verband met die rol wat die teks aan die leser uitdeel nie, maar die hele produksieproses van betekenis waar die produksiefaktore van die teks in ag geneem moet word.

Produksiefaktore roep die outeursvraagstuk na vore, wat ons op sy beurt, midde in die problematiek van die etiek van lees plaas. Om 'n verskil tussen die antieke outeur en die moderne leser te ontken, is om die outeur se reg om 'n bepaalde individu te wees, te misken. Om dit te misken is ' $n$ verdrukkende daad. Dit is eweneens onderdrukkend om te aanvaar dat kommunikasie tussen die antieke outeur en die moderne leser normaal kan verloop. Dit gaan hier dus oor die vraag na die geregtigheid van interpretasie waar die andere ervaar moet word as die andere en waar die andere toegelaat word om die andere te wees (vgl. Derrida, 1994:37). Die postmoderne plaas die huidige outeur ook voor die etiek van sy eie interpretasie. Dit hou 'n mens se interpretasie nederig.

\section{Bibliografie}

ALBERTZ, R. 1992. Religionsgeschichte Israels in alttestamentlicher Zeit.

Teil 1: Von den Anfängen bis zum Ende der Königszeit. Göttingen : Vandenhoeck \& Ruprecht.

ANON. 1995. Jong predikant-digters kom sterk na vore. Boekewêreld: 2 . (Bylaag tot Beeld.) Jul. 19. 
ARMSTRONG, K. 1993. A history of God. From Abraham to the present: the 4000 -year quest for God. London : Mandarin.

BAL, M. 1991. Lots of writing. Semeia, 54:77-102.

BEAL, T. 1992. Ideology and intertextuality: surplus of meaning and controlling the means of production. (In Fewel, F.D. ed. Reading between texts. Intertextuality and the Hebrew Bible. Louisville : John Knox Press. p. 27-40.)

BOTHA, J. 1986. Die Gereformeerde Skrifbeskouing en modeme metodes van verklaring van die Nuwe Testament. Koers, 51(3):259-286.

BOOTH, W.C. 1988. The company we keep. An ethics of fiction. Berkeley : University of California.

CARROL, R.P. 1993. The Hebrew Bible as literature - a misprision? Studia Theologica, 47:77-90.

CLINES, D.J.A. 1980. Story and poem: The Old Testament as literature and as Scripture. Interpretation, 34(7):115-127.

CLINES, D.J.A. 1992. Reading Esther from left to right. Contemporary strategies for reading a biblical text. (In Clines, D. ed. The Bible in three dimensions. Sheffield : Sheffield Academic Press. p. 31-52.)

DAVIES, P.R. 1995. Whose Bible is it anyway? Sheffield : Sheffield Academic Press.

DAY, L. 1995. Three faces of a queen. Characterisation in the Books of Esther. Sheffield : Sheffield Academic Press.

DEIST, F.E. 1986. Narrative texts. (In Deist, F.E. \& Vorster, W.S. reds. Woorde wat ver kom. Literatuur van die Ou Testament. Vol 1. Tafelberg : Kaapstad. p. 69-102.)

DEIST, F.E. 1991. Verslag: Wetenskapsteorie en vakmetodologie in Bybelwetenskaplike navorsing in Suid-Afrika. 'n Wetenskapsteoretiese en sosiaal-historiese studie. Volume 1. Samevattende verslag. Ongepubliseerd. RGN.

DEIST, F.E. 1994a. The Bible as literature: Whose literature? Old Testament Essays, 7(3):327-342.

DEIST, F.E. 1994b. South African Old Testament Studies and the future. Old Testament Essays, 7(4):33-51.

DERRIDA, J. 1994. The deconstruction of actuality. An interview with Jacques Derrida. Radical Philosophy, 68:28-41.

DU TOIT, C.W. 1988. Aspekte van die postmodernistiese idioom in die teologie. Theologia Evangelica, 21(1):36-50.

FISHER, W. 1987. Human communication as narration: toward a philosophy of reason, value, and action. Columbia : University of South Carolina Press. 
Bybellees en wederstrewigheid - lesersreaksie op God en Ester

GOLDMAN, S. 1990. Narrative and ethical ironies in Esther. Journal for the Study of the Old Testament, 47:15-31.

GOOSEN, D.P. 1992. Die teologiese onderwys as dialogiese gebeure - 'n perspektief. Theologia Evangelica, 25(1):24-34.

HEIDEGGER, M. 1959. Gelassenheit. Tübingen : Neske.

HELBERG, J.L. 1983a. Die Here regeer. Openbaringslyn deur die Ou Testament. Pretoria : NG Kerkboekhandel.

HELBERG, J.L. 1983b. Verklaring en prediking van die Ou Testament. Potchefstroom : PTP.

IJSSELING, S. 1994. Apollo, Dionysos, Aphrodite en de anderen. Griekse goden in de hedendaagse filosofie. Amsterdam : Boom.

JAMESON, F. 1981. The political unconscious. Narrative as a socially symbolic act. London : Methuen.

JAUß, H-R. 1987. The book of Jonah. A paradigm of the 'hermeneutics of strangeness'. Minneapolis : University of Minnesota.

JAUß, H-R. 1989. Ästhetische Erfahrung und literarische Hermeneutik. Suhrkamp : Frankfurt am Main.

JORDAAN, G.J.C. 1991. Skrifbeskouing: deurslaggewende faktor by Skrifverklaring. Inougurele rede gehou op 7 Junie 1991. Wetenskaplike Bydraes van die PU vir CHO. Reeks H. Inougurele rede no 125. Potchefstroom : Departement Sentrale Publikasies, PU vir CHO.

KEEGAN, T.J. 1995. Biblical criticism and the challenge of postmodernism. Biblical Interpretation, 3(1):1-14).

KRUGER, J.S. 1995. Along edges. Religion in South Africa. Bushman, Christian, Buddhist. Pretoria : University of South Africa.

LE ROUX, J.H. 1994. Die aard en plek van teologiese opleiding aan 'n universiteit. Ned. Geref. Teologiese Tydskrif, 34(4):589-599.

LOADER, J.A. 1986. Tekste met 'n wysheidsperspektief. (In Deist, F.E. \& Vorster, W.S. reds. Woorde wat ver kom. Literatuur van die Ou Testament. Vol. 1. Tafelberg : Kaapstad. p. 103-122.)

LOADER, J.A. 1992. Das Buch Esther. (In Müller, H-P; Kaiser, O. \& Loader J.A. Das Alte Testament Deutsch. Das Hohelied, Klagelieder, Das Buch Esther. Göttingen : Vandenhoeck. p. 200-280.)

MOORE, G.A. 1988. Esther. Introduction, translation and notes. The Anchor Bible. Doubleday : New York.

MOSALA, 1. 1992. The implications of the text of Esther for African women's struggle for liberation in South Africa. Semeia, 59:129-137.

OTTO, R. 1950. The idea of the Holy. An inquiry into the non-rational factor in the idea of the divine and its relation to the rational. Tr. by J.W. Harvey. Oxford : University Press. 
Gerrie Snyman

ROWLAND, R.C. 1987. Narrative: mode of discourse or paradigm? Communication Monographs, 54(3):264-275.

SANKS, T.H. 1993. David Tracy's theological project: an overview and some implications. Theological Studies, 54:698-727.

SCHOLES, R. 1968. The elements of fiction. New York : Oxford University Press.

SNYMAN, G.F. 1994. Who is responsible for Uzzah's death? Rhetoric in 1 Chronicles 13. Paper presented at Conference on Religion and Rhetoric, Unisa.

SNYMAN, G.F. 1995. Foreign bedfellows: the case of the 'foreign woman' in the Second Temple Period. Lesing gelewer in September 1995 by die OTWSA, Universiteit van Port Elizabeth.

TOERIEN, B. 1995. Ouer digter gesels met jonger digter. Boekewêreld: 6, Jul. 19.

TOULMIN, S. 1990. Cosmopolis: the hidden agenda of modernity. New York: The Free Press.

TRACY, D. 1981. The analogical imagination. Christian theology and the culture of pluralism. New York : Crossroad.

VAN HUYSSTEEN, W. 1987. The realism of the text: A perspective on biblical authority. Pretoria : University of South Africa.

VORSTER, J.N. 1994. Creatures creating creators: the potential of rhetoric. Religion and Theology, 1(2):118-135.

WYNGAARD, H. 1995. Adam Small praat hart uit oor rol in SA. Boekewêreld:3, Jul. 19.

ZAAIMAN, R. 1995. Spieël Triomf Christelike waardes? Boekewêreld:1, Jul. 19. 